\title{
Lactobacillus aquaticus sp. nov., isolated from a Korean freshwater pond
}

\author{
Rosario Mañes-Lázaro, ${ }^{1}$ Jaeho Song, ${ }^{2}$ Isabel Pardo, ${ }^{1}$ Jang-Cheon Cho $^{2}$ \\ and Sergi Ferrer ${ }^{1}$
}

Correspondence

Sergi Ferrer

Sergi.Ferrer@uv.es

\author{
${ }^{1}$ ENOLAB - Laboratorio de Microbiología Enológica, Departamento de Microbiología y Ecología, \\ Facultad de Biología, Universidad de Valencia, Dr Moliner 50, 46100 Burjasot, Valencia, Spain \\ ${ }^{2}$ Division of Biology and Ocean Sciences, Inha University, Yonghyun-Dong 253, Nam-Gu, Incheon \\ 402-751, Republic of Korea
}

\begin{abstract}
A Lactobacillus strain, IMCC $1736^{\top}$, was isolated recently from a Korean freshwater pond following an extensive study of the microbial community in this ecosystem. Its 16S rRNA gene was sequenced and phylogenetic analysis placed this strain within the Lactobacillus salivarius group, closely related to Lactobacillus satsumensis NRIC $0604^{\top}$, with $97.9 \%$ sequence similarity. In the present work, the taxonomic status of strain IMCC $1736^{\top}$ has been re-evaluated. It was characterized phylogenetically, genotypically and phenotypically and, based on DNA-DNA hybridization values, this strain represents a novel Lactobacillus species. Strain IMCC1736 ${ }^{\top}$ can be differentiated genotypically from its closest relatives by randomly amplified polymorphic DNA analysis and ribotyping patterns; phenotypically, it can be distinguished by its inability to grow in $5 \% \mathrm{NaCl}$ and at $\mathrm{pH} 3.3$ and by certain carbohydrate fermentations. Strain IMCC1736 ${ }^{\top}$ is Grampositive, catalase-negative and microaerophilic. Cells are motile rods and show homofermentative metabolism. The name Lactobacillus aquaticus sp. nov. is proposed, with strain IMCC1736 ${ }^{\top}$ $\left(=\right.$ CECT $7355^{\top}=$ DSM $\left.21051^{\top}\right)$ as the type strain.
\end{abstract}

The genus Lactobacillus belongs to the lactic acid bacteria group and is a highly heterogeneous genus in terms of the metabolic pathways, DNA G $+C$ contents and source of its members. Lactobacilli are almost ubiquitous; they are found in any environment where carbohydrates are available, although they are most frequently present in vegetable or animal food, fermented foods and beverages, mucosal membranes of humans and animals and plant material (Hammes \& Hertel, 2006; Bernardeau et al., 2008). Although isolation of lactic acid bacteria from environmental samples is not common, some isolates have been reported from sewage (Weiss et al., 1981), soils (Chen et al., 2005; Yanagida et al., 2005), the deep subsea floor (Toffin et al., 2005) and coastal marsh sediments (Zamudio-Maya et al., 2008); other isolates have been found associated with marine organisms (Ishikawa et al., 2003; Vela et al., 2008). Even though some lactobacilli have been isolated from aquatic sources (Yanagida et al., 2007), they have not been found in seawater.

\footnotetext{
The GenBank/EMBL/DDBJ accession number for the 16S rRNA gene sequence of strain IMCC $1736^{\top}$ is DQ664203.

Phenotypic characteristics of strain IMCC $1736^{\top}$ and closely related strains are available as supplementary material with the online version of this paper.
}

Song et al. (2007), carrying out an extensive study of the microbial diversity in a Korean lake, isolated strain IMCC $1736^{\mathrm{T}}$, which was most closely related to Lactobacillus satsumensis NRIC $0604^{\mathrm{T}}$, with $97.9 \% 16 \mathrm{~S}$ rRNA gene sequence similarity, and placed it in the Lactobacillus salivarius phylogenetic group (Felis \& Dellaglio, 2007). In the past few years, some novel lactobacilli belonging to this group have been isolated from several sources, such as wild mouse faeces and wine (Osawa et al., 2006; Rodas et al., 2006). This heterogeneous genus is expanding constantly since novel species are being described continually and, thus, its phylogenetic structure is changing dramatically (Felis \& Dellaglio, 2007). In this study, an in-depth phylogenetic, genotypic and phenotypic characterization of strain IMCC $1736^{\mathrm{T}}$ and its closest relatives is reported. On the basis of these results, a novel species of the genus Lactobacillus is proposed.

Strain IMCC $1736^{\mathrm{T}}$ was isolated from the surface of a eutrophic freshwater pond in Korea. Reference strains [Lactobacillus mali strains DSM 20444 ${ }^{\mathrm{T}}$, CECT 4149, Lb44 and Lb206, L. satsumensis strains DSM $16230^{\mathrm{T}}$, CECT 7371 and ENOLAB 4555, 'Lactobacillus uvarum' strains CECT 7335 (the proposed type strain), 24 and 68 and Lactobacillus vini CECT 5924 ${ }^{\mathrm{T}}$ ] and strain IMCC $1736^{\mathrm{T}}$ were grown in MRS broth (Scharlab) supplemented with $0.5 \mathrm{~g}$ L-cysteine hydrochloride $1^{-1}$ under the conditions described by Rodas et al. (2003). 
The almost-complete 16S rRNA gene sequence of strain IMCC $1736^{\mathrm{T}}$ (1528 bp) was obtained using the protocol described by Rodas et al. (2005) and, together with sequences from its nearest relatives, including the recently described 'L. uvarum' (Mañes-Lázaro et al., 2008), was subjected to phylogenetic analysis. The 16S rRNA gene sequence of strain IMCC $1736^{\mathrm{T}}$ was aligned with those of members of the genus Lactobacillus using the ARB software package. Several reconstruction methods (neighbour-joining, maximum-parsimony and maximum-likelihood) were applied in the PAUP ${ }^{*} 4.0$ software package to infer the phylogeny of strain IMCC $1736^{\mathrm{T}}$. The $16 \mathrm{~S}$ rRNA gene sequence of the isolate showed $99.8 \%$ sequence similarity with that of ' $L$. uvarum' 8 (=CECT 7335), $97.5 \%$ with $L$. mali DSM $20444^{\mathrm{T}}$ and L. satsumensis NRIC $0604^{\mathrm{T}}, 96.1 \%$ with L. vini CECT $5924^{\mathrm{T}}, 95.7 \%$ with Lactobacillus ghanensis $\mathrm{L}_{489^{\mathrm{T}}}$ and $95.1 \%$ with Lactobacillus nagelii NRIC $0559^{\mathrm{T}}$. In all of the phylogenetic trees (Fig. 1), strain IMCC $1736^{\mathrm{T}}$ formed a robust clade together with ' $L$. uvarum' 8 . Because 16S rRNA gene sequence similarities between the isolate and strains of some species of the genus Lactobacillus were too high to define a novel species, DNADNA hybridization experiments were required.

DNA-DNA hybridization experiments were performed as described by Ziemke et al. (1998) between strain IMCC $1736^{\mathrm{T}}$ and 'L. uvarum' strains CECT 7335, 24 and 68 and L. mali DSM $20444^{\mathrm{T}}$. The results, expressed as mean percentages based on three independent hybridization experiments, were $41.74,53.09,43.29$ and $37.5 \%$, respectively. Reciprocal hybridization experiments using genomic DNA of ' $L$. uvarum' CECT 7335 as template rendered a value of $41.49 \%$ with strain IMCC $1736^{\mathrm{T}}$. These values were below $70 \%$, confirming that IMCC $1736^{\mathrm{T}}$ is a member of a novel species (Stackebrandt \& Goebel, 1994).

16S-ARDRA (amplified rDNA restriction analysis), ISR (internal spacer region) analysis, RAPD (randomly amplified polymorphic DNA) analysis and ribotyping were used to characterize this strain genotypically, as described previously (Rodas et al., 2003, 2005; Chenoll et al., 2006). Strain IMCC $1736^{\mathrm{T}}$ could be differentiated from the reference strains by RAPD and ribotyping profiles, but not by the other techniques based on ribosomal gene analysis. As deduced from the dendrogram built with different fingerprinting analyses, five clusters could be delineated at $>75 \%$ similarity, corresponding to the five species analysed (Fig. 2). Genotypically, L. satsumensis was most closely related to strain IMCC $1736^{\mathrm{T}}(63.23 \%$ similarity).

The DNA G $+\mathrm{C}$ content of strain $\mathrm{IMCC} 1736^{\mathrm{T}}$ was determined by hydrolysing the DNA enzymically and quantifying the nucleosides by HPLC as reported previously by Tamaoka \& Komagata (1984) and Ziemke et al. (1998). The DNA G $+C$ content was $39.15 \pm 0.07 \mathrm{~mol} \%$, a value within the range (32-53 mol\%) established for the genus Lactobacillus.

To test for the presence of meso-diaminopimelic acid (meso-DAP), whole cells were hydrolysed by incubating them for $15 \mathrm{~h}$ at $100{ }^{\circ} \mathrm{C}$ with $4 \mathrm{M} \mathrm{HCl}$ and the hydrolysates were subjected to TLC on cellulose plates using the solvent system of Rhuland et al. (1955). Results revealed that strain IMCC $1736^{\mathrm{T}}$ contained meso-DAP.

Strain IMCC $1736^{\mathrm{T}}$ is a Gram-positive, catalase-negative and microaerophilic lactobacillus. Cells were motile when

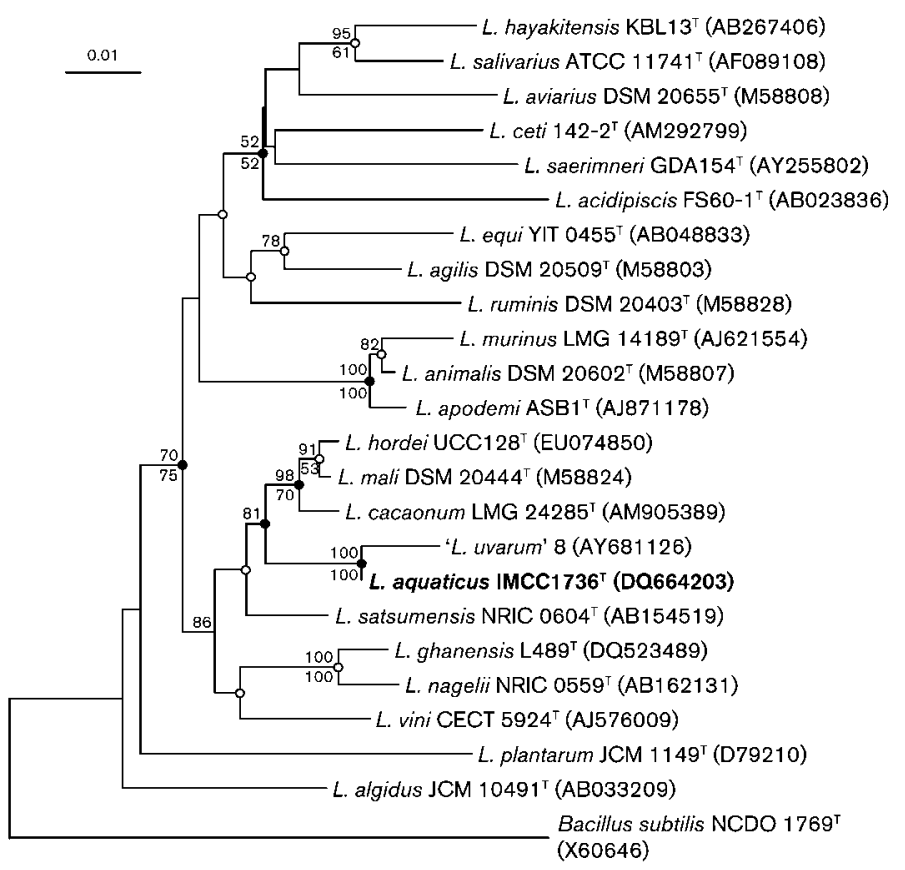

Fig. 1. Neighbour-joining phylogenetic tree based on 16S rRNA gene sequences showing relationships between strain IMCC $1736^{\top}$ and other Lactobacillus species. Bootstrap values above $50 \%$ from neighbour-joining (above nodes) and maximum-likelihood (below nodes) methods are shown. Filled and open circles respectively indicate nodes recovered reproducibly by all treeing methods or by two treeing methods. Bar, 0.01 substitutions per nucleotide position. The sequence from Bacillus subtilis NCDO $1769^{\top}$ was used as an outgroup. 


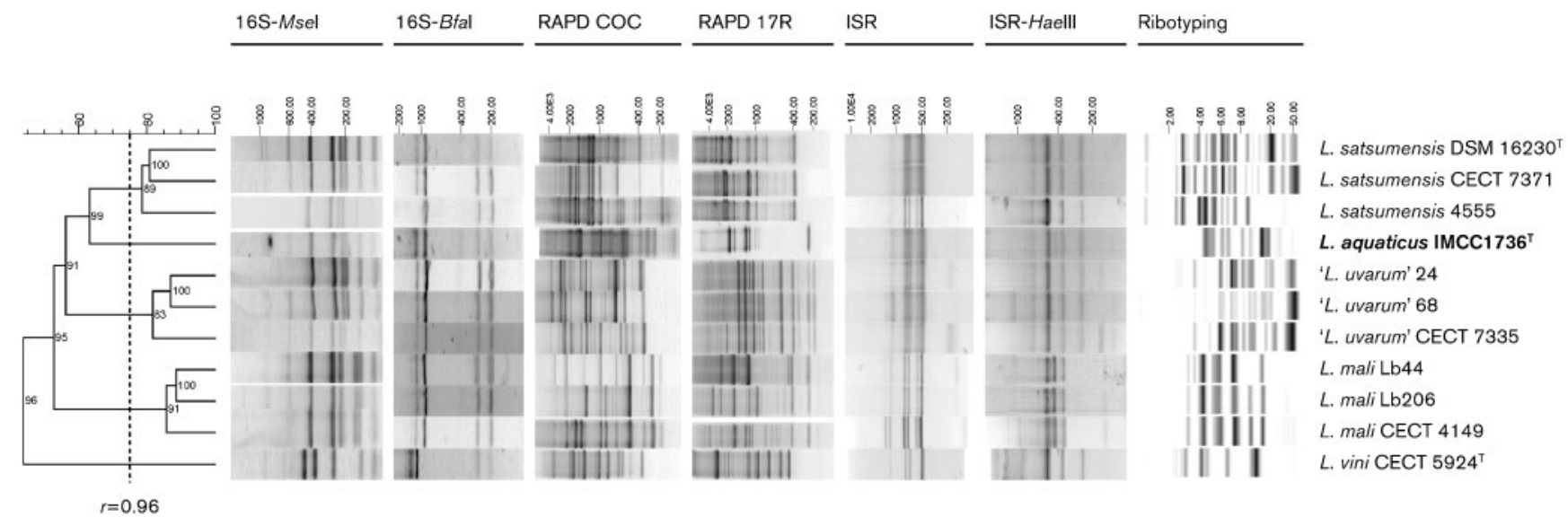

Fig. 2. Dendrogram derived from comparison of the combined 16S-ARDRA (Msel and Bfal), RAPD analysis (COC and 17R), ISR and ISR-ARDRA (HaellI) and ribotyping, obtained from strain IMCC1736 ${ }^{\top}$ and reference strains. Levels of similarity between patterns were calculated by using the similarity coefficient of each technique and the clustering is based on the UPGMA method. At similarities $>75 \%$, five clusters could be delineated, corresponding to the five species analysed. The calculated global cophenetic correlation value for the global analysis was 96 .

tested in MRS soft agar and when observed on wet mounts (Rodas et al., 2006). No gas was released from glucose and it did not ferment gluconate or pentoses; thus, it is considered to be obligately homofermentative. The ability of strain IMCC $1736^{\mathrm{T}}$ and reference species to ferment carbohydrates was tested on API $50 \mathrm{CHL}$ galleries (bioMérieux) according to the instructions of the manufacturer; detailed results are given in Supplementary Table S1 (available in IJSEM Online). Strain IMCC1736 ${ }^{\mathrm{T}}$ differed from ' $L$. uvarum', its closest relative, in its inability to grow in $5 \% \mathrm{NaCl}$ and to ferment turanose (Table 1). In addition, strain IMCC $17366^{\mathrm{T}}$ was able to grow at $45{ }^{\circ} \mathrm{C}$ and ferment methyl $\alpha$-D-mannoside and cellobiose, whereas ' $L$. uvarum' was not.

In conclusion, in view of the low DNA-DNA relatedness between strain IMCC1736 ${ }^{\mathrm{T}}$ and other members of the genus Lactobacillus, together with its phenotypic characteristics, strain IMCC $1736^{\mathrm{T}}$ represents a novel species in the genus Lactobacillus, for which the name Lactobacillus aquaticus sp. nov. is proposed.

\section{Description of Lactobacillus aquaticus sp. nov.}

Lactobacillus aquaticus (a.qua'ti.cus. L. masc. adj. aquaticus from water, aquatic).

Gram-positive, motile, non-spore-forming rods, 1.01$1.38 \mu \mathrm{m}$ wide and $1.74-3.84 \mu \mathrm{m}$ long. Cells are found singly, in pairs and in short chains. Microaerophilic. Colonies on MRS agar after 4 days incubation at $28{ }^{\circ} \mathrm{C}$ are $1.5-2.0 \mathrm{~mm}$ in diameter, smooth, circular, regular and white. Catalase-negative. Growth occurs at $15-45{ }^{\circ} \mathrm{C}$ and $\mathrm{pH} 4.5-8.0$, but not at $\mathrm{pH} 3.3$ or in 5 or $10 \% \mathrm{NaCl}$. Homofermentative. Ammonia is not produced from arginine and mannitol is not produced from fructose.
Exopolysaccharide is produced from sucrose. Ferments glucose, fructose, mannose, mannitol, methyl $\alpha$-D-mannoside, methyl $\alpha$-D-glucoside, $N$-acetylglucosamine, amygda-

Table 1. Differential phenotypic characteristics of strain IMCC $1736^{\top}$ and its closest phylogenetic neighbours

Strains: 1 , L. aquaticus sp. nov. IMCC $1736^{\mathrm{T}}$; 2, 'L. uvarum' CECT 7335; 3, L. mali DSM $20444^{\mathrm{T}}$; 4, L. satsumensis DSM $16230^{\mathrm{T}}$; 5, L. vini CECT $5924^{\mathrm{T}}$; 6, L. nagelii CECT $5983^{\mathrm{T}}$. +, Positive; -, negative; $\mathrm{w}$, weak reaction. Data were obtained in this study.

\begin{tabular}{|lccccccc|}
\hline Characteristic & $\mathbf{1}$ & $\mathbf{2}$ & $\mathbf{3}$ & $\mathbf{4}$ & $\mathbf{5}$ & $\mathbf{6}$ \\
\hline Growth in MRS with/at: & & & & & & & \\
$5 \% \mathrm{NaCl}$ & - & + & - & + & + & + \\
$\mathrm{pH} 3.3$ & - & - & $\mathrm{W}$ & + & + & + \\
$45{ }^{\circ} \mathrm{C}$ & $\mathrm{W}$ & - & - & $\mathrm{w}$ & + & - \\
Fermentation of: & & & & & & \\
L-Arabinose & - & - & - & - & + & - \\
D-Galactose & - & - & - & + & - & + \\
L-Sorbose & - & - & - & + & - & + \\
L-Rhamnose & - & - & - & + & - & + \\
D-Mannitol & + & + & + & + & - & + \\
D-Sorbitol & - & - & + & + & - & + \\
Methyl $\alpha$-D-mannoside & + & - & - & + & + & - \\
Methyl $\alpha$-D-glucoside & + & + & - & + & - & + \\
Salicin & + & + & - & + & + & + \\
Cellobiose & + & - & + & - & + & + \\
Maltose & + & + & - & + & + & + \\
$\beta$-Gentiobiose & + & + & + & + & + & - \\
Turanose & - & + & - & + & - & - \\
D-Tagatose & - & - & - & + & - & - \\
Exopolysaccharide production & + & + & + & + & - & + \\
from sucrose & & & & & & & \\
& & & & & & & \\
\hline
\end{tabular}


lin, arbutin, salicin, cellobiose, maltose, sucrose, trehalose and $\beta$-gentiobiose. Hydrolyses aesculin. Does not ferment glycerol, erythritol, D- or L-arabinose, ribose, D- or Lxylose, adonitol, methyl $\beta$-xyloside, galactose, L-sorbose, rhamnose, dulcitol, inositol, sorbitol, lactose, melibiose, inulin, melezitose, raffinose, starch, glycogen, xylitol, turanose, D-lyxose, D-tagatose, D- or L-fucose, D- or Larabitol, gluconate or 2- or 5-ketogluconate.

The type strain is IMCC $1736^{\mathrm{T}}\left(=\mathrm{CECT} 7355^{\mathrm{T}}=\right.$ DSM $21051^{\mathrm{T}}$ ), isolated in 2005 (Song et al., 2007) from a eutrophic freshwater pond. The DNA G $+\mathrm{C}$ content of the type strain is $39.15 \pm 0.07 \mathrm{~mol} \%$ (HPLC).

\section{Acknowledgements}

This work was supported partially by RM2007-00007-00-00 and by the $21 \mathrm{C}$ Frontier programme of Microbial Genomics and Applications from the MEST, Korea. We wish to thank Mercedes Urdiain and Ramón Rosselló-Mora for kindly helping with the hybridization and $\mathrm{G}+\mathrm{C}$ analysis.

\section{References}

Bernardeau, M., Vernoux, J. P., Henri-Dubernet, S. \& Guéguen, M. (2008). Safety assessment of dairy microorganisms: the Lactobacillus genus. Int J Food Microbiol 126, 278-285.

Chen, Y.-S., Yanagida, F. \& Shinohara, T. (2005). Isolation and identification of lactic acid bacteria from soil using an enrichment procedure. Lett Appl Microbiol 40, 195-200.

Chenoll, E., Macián, M. C. \& Aznar, R. (2006). Lactobacillus tucceti sp. nov., a new lactic acid bacterium isolated from sausage. Syst Appl Microbiol 29, 389-395.

Felis, G. E. \& Dellaglio, F. (2007). Taxonomy of lactobacilli and bifidobacteria. Curr Issues Intest Microbiol 8, 44-61.

Hammes, W. P. \& Hertel, C. (2006). The genera Lactobacillus and Carnobacterium. In The Prokaryotes, 3rd edn, vol. 4, pp. 320-403. Edited by M. Dworkin, S. Falkow, E. Rosenberg, K. H. Schleifer \& E. Stackebrandt. New York: Springer.

Ishikawa, M., Nakajima, K., Yanagi, M., Yamamoto, Y. \& Yamasato, K. (2003). Marinilactibacillus psychrotolerans gen. nov., sp. nov., a halophilic and alkaliphilic marine lactic acid bacterium isolated from marine organisms in temperate and subtropical areas of Japan. Int J Syst Evol Microbiol 53, 711-720.

Mañes-Lázaro, R., Ferrer, S., Rosselló-Mora, R. \& Pardo, I. (2008). Lactobacillus uvarum sp. nov. - a new lactic acid bacterium isolated from Spanish Bobal grape must. Syst Appl Microbiol 31, 425-433.

Osawa, R., Fujisawa, T. \& Pukall, R. (2006). Lactobacillus apodemi sp. nov., a tannase-producing species isolated from wild mouse faeces. Int J Syst Evol Microbiol 56, 1693-1696.
Rhuland, L. E., Work, E., Denman, R. F. \& Hoare, D. S. (1955). The behavior of the isomers of $\alpha, \varepsilon$-diaminopimelic acid on paper chromatograms. J Am Chem Soc 77, 4844-4846.

Rodas, A. M., Ferrer, S. \& Pardo, I. (2003). 16S-ARDRA, a tool for identification of lactic acid bacteria isolated from grape must and wine. Syst Appl Microbiol 26, 412-422.

Rodas, A. M., Ferrer, S. \& Pardo, I. (2005). Polyphasic study of wine Lactobacillus strains: taxonomic implications. Int J Syst Evol Microbiol 55, 197-207.

Rodas, A. M., Chenoll, E., Macián, M. C., Ferrer, S., Pardo, I. \& Aznar, R. (2006). Lactobacillus vini sp. nov., a wine lactic acid bacterium homofermentative for pentoses. Int J Syst Evol Microbiol 56, 513-517.

Song, J., Seung-Jo, Y. \& Cho, J.-C. (2007). "Bring to Lab" of 19 novel species among 60 isolates retrieved from a freshwater pond. J Microbiol Biotechnol 17, 168-175.

Stackebrandt, E. \& Goebel, B. M. (1994). Taxonomic note: a place for DNA-DNA reassociation and 16S rRNA sequence analysis in the present species definition in bacteriology. Int J Syst Bacteriol 44, 846-849.

Tamaoka, J. \& Komagata, K. (1984). Determination of DNA base composition by reversed-phase high-performance liquid chromatography. FEMS Microbiol Lett 25, 125-128.

Toffin, L., Zink, K., Kato, C., Pignet, P., Bidault, A., Bienvenu, N., Birrien, J.-L. \& Prieur, D. (2005). Marinilactibacillus piezotolerans sp. nov., a novel marine lactic acid bacterium isolated from deep subseafloor sediment of the Nankai Trough. Int J Syst Evol Microbiol 55, 345-351.

Vela, A. I., Fernández, A., Espinosa de los Monteros, A., Goyache, J., Herraez, P., Tames, B., Cruz, F., Domínguez, L. \& FernándezGarayzábal, J. F. (2008). Lactobacillus ceti sp. nov., isolated from beaked whales (Ziphius cavirostris). Int J Syst Evol Microbiol 58, 891-894.

Weiss, N., Schillinger, U., Laternser, M. \& Kandler, O. (1981). Lactobacillus sharpeae sp. nov. and Lactobacillus agilis sp. nov., two new species of homofermentative, meso-diaminopimelic acid-containing lactobacilli isolated from sewage. Zentralbl Bakteriol Mikrobiol Hyg 1 Abt C 2, 242-253.

Yanagida, F., Chen, Y.-S. \& Shinohara, T. (2005). Isolation and characterization of lactic acid bacteria from soils in vineyards. J Gen Appl Microbiol 51, 313-318.

Yanagida, F., Chen, Y.-S. \& Yasaki, M. (2007). Isolation and characterization of lactic acid bacteria from lakes. J Basic Microbiol 47, 184-190.

Zamudio-Maya, M., Narváez-Zapata, J. \& Rojas-Herrera, R. (2008). Isolation and identification of lactic acid bacteria from sediments of a coastal marsh using a differential selective medium. Lett Appl Microbiol 46, 402-407.

Ziemke, F., Höfle, M. G., Lalucat, J. \& Rosselló-Mora, R. (1998). Reclassification of Shewanella putrefaciens Owen's genomic group II as Shewanella baltica sp. nov. Int J Syst Bacteriol 48, 179-186. 